\title{
Refining of Secondary Aluminum: Important Chemical Factors
}

\author{
GEOFFREY K. SIGWORTH (1D ${ }^{1,2}$ \\ 1.-GKS Engineering Services, Harrisonburg, Virginia 22802, USA. 2.—e-mail: \\ gksigworth@gmail.com
}

\begin{abstract}
There are important economic and environmental incentives to recycling. Unfortunately, secondary aluminum frequently contains undesirable impurity elements. These limit the amount of secondary material that can be recovered, since the usual practice has been to meet alloy specifications by dilution (that is, by blending with primary metal). In 2019, China curtailed the importation of scrap metal, which changed the scrap market in North America. The price differential between secondary and primary metal suddenly became 20 or 30 cents a pound, sometimes more. This differential was large enough that producers began to ask: "Is there a refining process we can we use to recover this scrap?" This paper is an attempt to answer this question. Chemical factors which make it possible (or impossible) to remove an impurity are reviewed in detail. Example calculations are presented and some important alloying elements are considered individually.
\end{abstract}

\section{INTRODUCTION}

The first step in most refining processes is to melt the secondary aluminum. The second step is to produce a chemical reaction between the molten metal and a second phase. In other words, we desire to remove impurities from a heat of metal via the second phase. There are three possible reactions:

1. Liquid-vapor: In this case, one introduces a reactive gas into or upon the surface of the metal. Vacuum refining may also be employed to remove elements having a high vapor pressure.

2. Liquid-liquid: The most common example of this process is to add reactive salts or fluxes to the furnace.*

3. Liquid-solid: It is possible to form a solid compound containing an impurity. The compound can then be removed by filtration, sedimentation, or centrifuging. Also, there is often a redistribution of solute elements when aluminum freezes. In this case, a fractional crystallization (partial solidification) process may be

\footnotetext{
*Another example is an electrolytic refining process, as in the Hoopes cell. This is an expensive process, and will not be considered here.
}

(Received April 18, 2021; accepted June 21, 2021;

published online July 23, 2021) used to refine secondary metal.

The third possibility is easily evaluated by looking at the phase diagram of the element with aluminum. Consider the $\mathrm{Al}-\mathrm{Fe}$ system, for example. At the eutectic temperature $\left(655^{\circ} \mathrm{C}\right)$ solid aluminum containing $0.05 \% \mathrm{Fe}$ is in equilibrium with liquid containing $1.9 \% \mathrm{Fe}$. Hence, the distribution coefficient for iron is:

$$
k_{\mathrm{Fe}}=\frac{\% \mathrm{Fe}_{\text {solid }}}{\% \mathrm{Fe}_{\text {liquid }}}=\frac{0.05}{1.9}=0.026
$$

In $\mathrm{Al}-\mathrm{Fe}$ melts, the first aluminum to freeze contains less than $3 \%$ of the iron contained in the liquid phase. The other $97 \%$ of the iron remains in the liquid. Hence, fractional crystallization is an excellent candidate process to remove iron from secondary aluminum.**

Evaluation of the first two processes listed above requires more effort and is the focus of this paper. However, a few simplifications are possible. Nearly all aluminum alloys contain more than 90-95\% aluminum. This means that the chemical or thermodynamic activity of aluminum will be close to

\footnotetext{
**Of course, the tendency for iron to segregate during solidification is the reason why it is so detrimental to ductility in structural aluminum products. Nearly all iron accumulates in the liquid phase during solidification, resulting in the formation of brittle, iron-containing intermetallic compounds.
} 
one. Therefore, we need to consider only the chemical properties of impurity elements dissolved in nearly pure, liquid aluminum.

Unfortunately, the thermodynamic data needed is usually difficult to obtain. It is sometimes 'buried' in obscure publications. Another problem is that information may be presented in various formats, some of which are not 'user friendly' for working calculations. Several different polynomial functions and thermodynamic models are used to represent thermodynamic properties. Also, different composition coordinates and standard states may be employed. The object of this publication is to provide the available thermodynamic data in a format that can be easily used by process metallurgists to evaluate refining processes.

At this point, it will be useful to provide a brief overview of the thermodynamic equations used to represent the chemical properties of elements dissolved in liquid aluminum. If this material is familiar, you may wish to skip the next section and go to the Discussion, where example calculations are given.

\section{THERMODYNAMIC EQUATIONS}

In scientific papers, the composition of an alloy is usually described by using mole fraction. In a multicomponent alloy, the mole fraction of each element is defined by:

$$
x_{i}=n_{i} / \sum_{1}^{c} n_{i} \quad(i=1,2,3, \ldots c)
$$

where $n_{i}$ is the number of moles of element ' $i$ ' present in the alloy solution; and where

$$
n_{i}=m_{i} / M_{i}
$$

and where $m_{i}$ is the mass (weight) of element ' $i$ ' in grams, and $M_{i}$ is the molecular weight of element ' $i$ '. In other words, the units of gram-moles are employed.

It may be useful to illustrate the above equations by an example. Consider an aluminium-7\% silicon alloy. Consider a weight of alloy equal to $100 \mathrm{~g}$. (This amount is solely for the sake of convenience in the calculations.) There are $93 \mathrm{~g}$ of aluminum and 7 $\mathrm{g}$ of silicon in the alloy. Consequently,

$$
\begin{gathered}
n_{A l}=93 / 26.98=3.447 \\
n_{S i}=7 / 28.08=0.249 \\
x_{S i}=0.249 /(0.249+3.447)=0.0673 \\
x_{A l}=3.447 /(0.249+3.447)=0.9327
\end{gathered}
$$

In this binary (two-component) Al-Si alloy, the molecular weights of aluminum and silicon are nearly the same. Thus, the mole fraction of $\mathrm{Si}$ (0.0673) is almost the same as the weight fraction $(0.07$ or $7 \%)$. However, this is not generally true. So, mole fraction is not convenient for 'engineering' calculations.

Why is this composition coordinate frequently used by scientists? In an ideal solution, the activity of a dissolved element is equal to its mole fraction. In general, the activity of element ' $i$ ' is defined by:

$$
a_{i}=\gamma_{i} x_{i}
$$

where $\gamma_{i}$ is the activity coefficient. For an ideal solution, the activity coefficient is equal to one.

We are considering aluminum-based alloys, where aluminum is the major constituent. The activity coefficient of pure aluminum is 1.0 , and in aluminum-based alloys it will be very close to one. For this reason, we are concerned only with the chemical properties of elements present in much smaller quantities. Thus, it is convenient to employ a formula known as Henry's law. In mathematical terms:

$$
\gamma_{i}^{o}=\frac{a_{i}}{x_{i}} \quad\left(\text { as } x_{i} \rightarrow 0\right)
$$

In other words, the activity coefficient of a dissolved element becomes a constant value $\left(\gamma^{o}\right)$ in dilute solutions.

As an example, we consider the free energy change associated with dissolution of a small amount of silicon in aluminum. Silicon is solid at normal melting temperatures, so its dissolution is described by:

$$
\mathrm{Si}(s) \rightarrow \underline{\mathrm{Si}}
$$

The dissolved silicon is indicated in Eq. 6 by underlining: Si. There will be a free energy change associated with the transfer of pure, solid silicon into a dilute solution of nearly pure aluminum. This is usually separated into an ideal component and an excess component. The excess component of the free energy change is equal to:

$$
R T \ln \gamma^{o}=\Delta G^{o}
$$

where $R$ is the gas constant ( $8.314 \mathrm{~J} /$ mole- $\mathrm{K})$, T is the thermodynamic temperature $\left({ }^{\circ} \mathrm{K}\right)$, and $\Delta G^{o}$ is the standard excess Gibbs free energy of the solution.

Table I gives the value of the Henrian activity coefficient $\left(\gamma^{o}\right)$ and excess free energy of solution for a number of alloying elements dissolved in aluminum. The activity coefficients have been tabulated for a temperature of $1000 \mathrm{~K}\left(727^{\circ} \mathrm{C}\right.$ or $\left.1340^{\circ} \mathrm{F}\right)$.

For most calculations, it will be more convenient to use weight percent (wt\%) as the composition coordinate. For this case, it is usual to define another Henrian activity, where: 
Table I. Thermodynamics of binary aluminum-based alloys

\begin{tabular}{|c|c|c|c|}
\hline Solution reaction & $\gamma^{\mathbf{o}}(1000 \mathrm{~K})$ & $\Delta \mathrm{G}^{\mathrm{o}}$ for mole fraction $(\mathrm{J} / \mathrm{mole})$ & $\Delta G^{\circ}$ for weight percent $(\mathrm{J} / \mathrm{mole})$ \\
\hline $\mathrm{Ag}(\mathrm{s}) \rightarrow \mathrm{Ag}$ & 0.53 & $18,620-23.870 \mathrm{~T}$ & $18,620-73.676 \mathrm{~T}$ \\
\hline $\mathrm{Au}(\mathrm{s}) \rightarrow \overline{\mathrm{Au}}$ & $\left(2.0 \times 10^{-5}\right)$ & $(-57,175-32.970 \mathrm{~T})$ & $(-57,175-87.782 \mathrm{~T})$ \\
\hline $\mathrm{B}(\mathrm{s}) \rightarrow \underline{\mathrm{B}}$ & 19.6 & $61,700-36.941 \mathrm{~T}$ & $61,700-67.622 \mathrm{~T}$ \\
\hline $\mathrm{Ba}(\mathrm{l}) \rightarrow \mathrm{Ba}$ & $5.1 \times 10^{-5}$ & $-106,200+23.957 \mathrm{~T}$ & $-106,200-27.856 \mathrm{~T}$ \\
\hline $\mathrm{Be}(\mathrm{s}) \rightarrow \overline{\mathrm{Be}}$ & 30.1 & $39,346-11.042 \mathrm{~T}$ & $39,346-40.210 \mathrm{~T}$ \\
\hline $\mathrm{Bi}(\mathrm{l}) \rightarrow \overline{\mathrm{Bi}}$ & 31.1 & $22,210+6.376 \mathrm{~T}$ & $22,210-48.928 \mathrm{~T}$ \\
\hline $\mathrm{C}(\mathrm{s}) \rightarrow \overline{\mathrm{C}}$ & $\left(1.1 \times 10^{4}\right)$ & $(112,681-35.259 \mathrm{~T})$ & $(112,681-66.816 \mathrm{~T})$ \\
\hline $\mathrm{Ca}(1) \rightarrow \overline{\mathrm{Ca}}$ & $7.6 \times 10^{-5}$ & $-99,579+20.723 \mathrm{~T}$ & $-99,579-20.852 \mathrm{~T}$ \\
\hline $\mathrm{Cd}(\mathrm{l}) \rightarrow \overline{\mathrm{Cd}}$ & 27.5 & $29,710-2.167 \mathrm{~T}$ & $29,710-52.316 \mathrm{~T}$ \\
\hline $\mathrm{Ce}(\mathrm{s}) \rightarrow \overline{\mathrm{Ce}}$ & $2.4 \times 10^{-7}$ & $-170,450+43.854 \mathrm{~T}$ & $-170,450-8.127 \mathrm{~T}$ \\
\hline $\mathrm{Co}(\mathrm{s}) \rightarrow \overline{\mathrm{Co}}$ & $1.4 \times 10^{-5}$ & $-138,655+45.470 \mathrm{~T}$ & $-138,655+0.687 \mathrm{~T}$ \\
\hline $\mathrm{Cr}(\mathrm{s}) \rightarrow \overline{\mathrm{Cr}}$ & $2.4 \times 10^{-3}$ & $-64,600+14.523 \mathrm{~T}$ & $-64,600-29.216 \mathrm{~T}$ \\
\hline $\mathrm{Cu}(\mathrm{s}) \rightarrow \overline{\mathrm{Cu}}$ & 0.035 & $-4623-23.171 \mathrm{~T}$ & $-4623-68.578 \mathrm{~T}$ \\
\hline $\mathrm{Fe}(\mathrm{s}) \rightarrow \overline{\mathrm{Fe}}$ & $1.3 \times 10^{-4}$ & $-83,717+9.624 \mathrm{~T}$ & $-83,717-34.710 \mathrm{~T}$ \\
\hline $\mathrm{Ga}(\mathrm{l}) \rightarrow \overline{\mathrm{Ga}}$ & 1.17 & $3481-2.176 \mathrm{~T}$ & $3481-48.354 \mathrm{~T}$ \\
\hline $\mathrm{Ge}(\mathrm{s}) \rightarrow \overline{\mathrm{Ge}}$ & 0.298 & $25,392-35.463 \mathrm{~T}$ & $25,392-81.982 \mathrm{~T}$ \\
\hline $1 / 2 \mathrm{H}_{2}(\mathrm{v}) \rightarrow \underline{\mathrm{H}}$ & - & - & $51,534+25.270 \mathrm{~T}$ \\
\hline $\operatorname{In}(1) \rightarrow \operatorname{In}$ & 16.7 & $28450-5.025 \mathrm{~T}$ & $28,450-55.350 \mathrm{~T}$ \\
\hline $\mathrm{La}(\mathrm{s}) \rightarrow \overline{\mathrm{La}}$ & $1.8 \times 10^{-6}$ & $-198,464+88.651 \mathrm{~T}$ & $-198,464+36.742 \mathrm{~T}$ \\
\hline $\mathrm{Li}(\mathrm{l}) \rightarrow \underline{\mathrm{Li}}$ & 0.31 & $-26,990+17.284 \mathrm{~T}$ & $-26,990-9.714 \mathrm{~T}$ \\
\hline $\mathrm{Mg}(\mathrm{l}) \rightarrow \overline{\mathrm{Mg}}$ & 0.35 & $-8,800$ & $-8,800-37.417 \mathrm{~T}$ \\
\hline $\mathrm{Mn}(\mathrm{s}) \rightarrow \mathrm{Mn}$ & 0.0014 & $-63,940+9.050 \mathrm{~T}$ & $-63,940-35.147 \mathrm{~T}$ \\
\hline $\mathrm{Mo}(\mathrm{s}) \rightarrow \overline{\mathrm{Mo}}$ & $1.8 \times 10^{-3}$ & $-82,460+30.041 \mathrm{~T}$ & $-82,460-18.791 \mathrm{~T}$ \\
\hline $\mathrm{Na}(\mathrm{l}) \rightarrow \overline{\mathrm{Na}}$ & 425 & $34,430+15.891 \mathrm{~T}$ & $34,430-21.064 \mathrm{~T}$ \\
\hline $\mathrm{Nd}(\mathrm{s}) \rightarrow \overline{\mathrm{Nd}}$ & $3.9 \times 10^{-7}$ & $-177,010+54.367 \mathrm{~T}$ & $-177,010+2.145 \mathrm{~T}$ \\
\hline $\mathrm{Ni}(\mathrm{s}) \rightarrow \overline{\mathrm{Ni}}$ & $3.3 \times 10^{-7}$ & $-122,290-1.844 \mathrm{~T}$ & $-122,290-46.590 \mathrm{~T}$ \\
\hline $\mathrm{Pb}(\mathrm{l}) \rightarrow \overline{\mathrm{Pb}}$ & 181 & $41,710+1.519 \mathrm{~T}$ & $41,710-53.714 \mathrm{~T}$ \\
\hline $\mathrm{Sb}(\mathrm{l}) \rightarrow \overline{\mathrm{Sb}}$ & 6.28 & $54,810-39.539 \mathrm{~T}$ & $54,810-90.352 \mathrm{~T}$ \\
\hline $\mathrm{Sc}(\mathrm{s}) \rightarrow \overline{\mathrm{Sc}}$ & $3.8 \times 10^{-5}$ & $-92,900+8.380 \mathrm{~T}$ & $-92,900-34.151 \mathrm{~T}$ \\
\hline $\mathrm{Si}(\mathrm{s}) \rightarrow \overline{\mathrm{Si}}$ & 0.42 & $40,080-47.350 \mathrm{~T}$ & $40.080-85.969 \mathrm{~T}$ \\
\hline $\mathrm{Sn}(\mathrm{l}) \rightarrow \overline{\mathrm{Sn}}$ & 6.12 & $24,455-9.393 \mathrm{~T}$ & $24,455-59.995 \mathrm{~T}$ \\
\hline $\mathrm{Sr}(\mathrm{s}) \rightarrow \overline{\mathrm{Sr}}$ & $4.9 \times 10^{-5}$ & $-100,000+17.531 \mathrm{~T}$ & $-100,000-30.547 \mathrm{~T}$ \\
\hline $\mathrm{Ti}(\mathrm{s}) \rightarrow \overline{\mathrm{Ti}}$ & $2.3 \times 10^{-4}$ & $-99,850+30.000 \mathrm{~T}$ & $-99,850-13.053 \mathrm{~T}$ \\
\hline $\mathrm{V}(\mathrm{s}) \rightarrow \overline{\mathrm{V}}$ & $2.2 \times 10^{-3}$ & $-60,950+10.070 \mathrm{~T}$ & $-60,950-33.501 \mathrm{~T}$ \\
\hline $\mathrm{Y}(\mathrm{s}) \rightarrow \underline{\overline{\mathrm{Y}}}$ & $\left(7.9 \times 10^{-6}\right)$ & $(-153,700+56.000 \mathrm{~T})$ & $(-153,700+7.799 \mathrm{~T})$ \\
\hline $\mathrm{Zn}(\mathrm{l}) \rightarrow \overline{\mathrm{Zn}}$ & 2.16 & $10,620-4.213 \mathrm{~T}$ & $10,620-49.857 \mathrm{~T}$ \\
\hline $\mathrm{Zr}(\mathrm{s}) \rightarrow \overline{\mathrm{Zr}}$ & $2.3 \times 10^{-4}$ & $-136,740+66.896 \mathrm{~T}$ & $-136,740+18.481 \mathrm{~T}$ \\
\hline
\end{tabular}

The thermodynamic temperature, $T$, is in degrees Kelvin. Values for free energy are in Joules/mole. The state of each element added to aluminum is indicated by $(s)$ for solid, $(l)$ for liquid and $(v)$ for vapor. Values enclosed in parentheses are best estimates considering the available data, and are of uncertain accuracy.

$$
a_{i}=f_{i} \cdot \% i
$$

and where

$$
f_{i}^{o}=\frac{a_{i}}{\% i} \equiv 1 \quad \text { as } \% i \rightarrow 0
$$

In this case, the activity coefficient $\left(f_{i}\right)$ is defined to be equal to one in the infinitely dilute solution (that is, in nearly pure aluminum). This means that the activity is numerically equal to its concentration in wt\%. This convention is most convenient for 'engineering' calculations, as shown later.
When using mole fraction, the pure element is the standard state. (The standard state is where the activity of ' $i$ ' is defined as being equal to one.) When using wt $\%$ as the composition coordinate, the standard state becomes a (hypothetical) $1 \mathrm{wt} \%$ solution. That is, $a_{i}$ is equal to one at $1 \mathrm{wt} \%$ ' $i$ '. This standard state may be hypothetical, because the solubility of ' $i$ ' can be less than $1 \mathrm{wt} \%$.

When using wt\% as the composition coordinate, the standard free energy of solution becomes:

$$
\Delta G_{i}^{o}=R T \ln \left(\gamma_{i}^{o} \cdot\left[M_{A l} / 100 M_{i}\right]\right)
$$

where: $M_{A l}$ is the molecular weight of aluminum, and $M_{i}$ is the molecular weight of the element ' $i$ ' 
The free energy of solution for wt $\%$ is also given in Table I. All values have the units of Joules per gram-mole. This means the gas constant should be equal to $8.314 \mathrm{~J} / \mathrm{mole}-\mathrm{K}$ in thermodynamic calculations based on these data.

A significant amount of additional information is available as electronic supplemental material (ESM). The ESM provides an extensive bibliography of the original publications consulted during this survey, and gives reasons for the selection of the values of free energy given in Table I. It should also be noted that the free energies in the table are valid only for relatively dilute solutions (that is, for nearly pure aluminum). For more highly alloyed melts, corrections may be made by using interaction coefficients. These are provided in the ESM in Table S-I, when the accuracy of the available data permits their calculation

\section{DISCUSSION}

To make meaningful and accurate thermodynamic calculations, it is necessary to have the standard free energies of formation for compounds, and the free energy of solution of the elements involved in the reaction. The first are found fairly easily. There are the JANAF tables, ${ }^{1}$ as well as a number of other excellent compilations. The second piece of information is available in Table I.

To illustrate how these thermodynamic data are used, some examples are presented. We first consider how alkali and alkaline earth metals behave in the presence of the reactive gases, chlorine or fluorine. Because aluminum is extremely reactive, only small pressures of $\mathrm{F}_{2}$ or $\mathrm{Cl}_{2}$ are required to produce $\mathrm{AlF}_{3}(\mathrm{~s})$ or $\mathrm{AlCl}_{3}(\mathrm{v})$. At typical melting temperatures $(1000 \mathrm{~K})$, $\mathrm{AlCl}_{3}$ is the principal component of the gas phase. (There is only about $1 \%$ of the $\mathrm{AlCl}$ and $\mathrm{AlCl}_{2}$ vapors.)

We first consider the reaction:

$$
\mathrm{Al}(\mathrm{l})+3 / 2 \mathrm{~F}_{2}(\mathrm{v})=\mathrm{AlF}_{3}(\mathrm{c})
$$

The standard free energy of formation at $1000 \mathrm{~K}^{1}$ is:

$$
\Delta \mathrm{G}^{o}=-1,250,040 \text { Joules } / \mathrm{g} \text { - mole }
$$

and from the relationship $\ln K=-\Delta G^{o} / R T$, at equilibrium we find:

$$
\left(P_{F_{2}}\right)^{3 / 2}=5.078 \times 10^{-66}
$$

or

$$
P_{F_{2}}=2.96 \times 10^{-44}
$$

At higher pressures, $\mathrm{AlF}_{3}$ will form. This equilibrium pressure is represented by the horizontal line at the top of Fig. 1.

As reactive metals are added to pure aluminum, there is the possibility of forming other compounds preferentially to the aluminum fluoride. Considering the case of magnesium, we find the standard free energy for the formation of magnesium fluoride in the JANAF Tables.

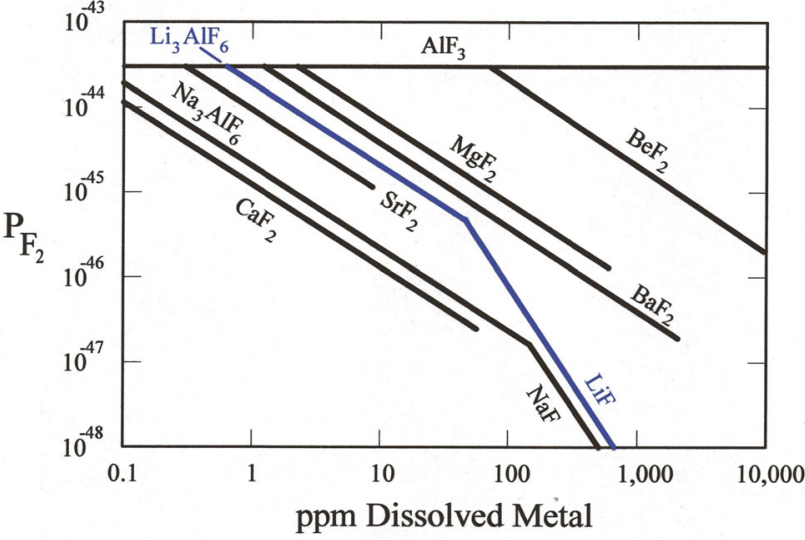

Fig. 1. Calculated equilibria for AI-M-F systems.

$$
\Delta \mathrm{G}_{f}^{o}=-1,125,647+175.602 T
$$

And using the data for the solution of $\mathrm{Mg}$ in Table I, we may calculate the equilibrium between dissolved magnesium and fluorine.

Thus, we find that

$$
(\% \mathrm{Mg}) \times\left(P_{F_{2}}\right)=6.40 \times 10^{-48}
$$

Equation 14 is represented by the sloping line for $\mathrm{MgF}_{2}$ in Fig. 1. It can be seen that the lines for $\mathrm{MgF}_{2}$ and $\mathrm{AlF}_{3}$ intersect at a $\mathrm{Mg}$ content of 2 parts per million (ppm).$^{\dagger}$ At higher contents of $\mathrm{Mg}$, the aluminum fluoride phase will be unstable. Similar calculations have been made for the other alkali and alkaline earth metals, and the results are also plotted in the figure. Lithium and sodium fluorides form compounds with aluminum fluoride. At low concentrations of $\mathrm{Li}$, the lithium aluminum fluoride, $\mathrm{Li}_{3} \mathrm{AlF}_{6}$, is more stable, than $\mathrm{LiF}$. When $\mathrm{Li}$ is more than about $20 \mathrm{ppm}$, the LiF phase is preferred. The situation with sodium is similar.

Figure 1 establishes the thermodynamic basis for the Treatment of Aluminum in Crucible (TAC) process $^{2}$. Hot aluminum from the pot room arrives in the cast house in transfer crucibles. Aluminum fluoride salt is mixed into the liquid metal with a graphite stirring paddle. The reacted salt is skimmed from the surface, and usually recycled by feeding into the electrolytic cells. The refined metal is delivered to the casting furnaces. The process was designed primarily to remove the $100-150 \mathrm{ppm}$ of dissolved sodium, which comes from the partial decomposition of the cryolite-based electrolyte used in the Hall cells. Lithium salts are sometimes added to the bath, ${ }^{*}$ and the TAC process is also effective in removing any dissolved lithium. With exception of

\footnotetext{
${ }^{\dagger}$ Note that 10,000 ppm equals $1 \mathrm{wt} \%$.

${ }^{*}$ In the 1980 s and 1990 s, lithium salts were added to the bath to increase current efficiency, so that the cell voltage could be lowered. It was later established ${ }^{3}$ that no improvement in current efficiency could be realized unless lower cell operating temperatures (possible with lithium salts) were also used.
} 


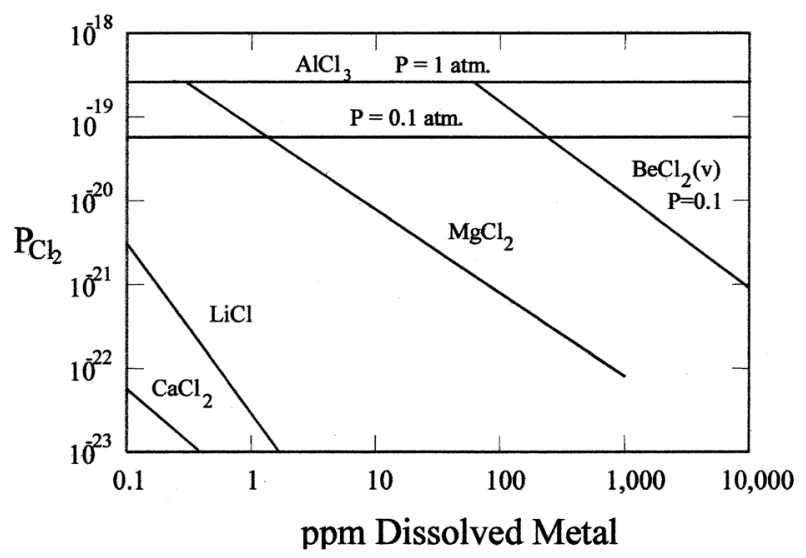

Fig. 2. Calculated equilibria for Al-M-Cl systems; the elements $\mathrm{Ba}$, $\mathrm{Sr}$, and $\mathrm{Na}$ are off-scale to the left of the figure.

beryllium, the TAC process would also effectively remove other elements plotted in Fig. 1.

Calculations for the chlorides are shown in Fig. 2. Because the stable species for aluminum is $\mathrm{AlCl}_{3}$ vapor, equilibrium lines are shown at two partial pressures. A pressure of 1 atmosphere corresponds to the case where pure chlorine is used to flux the metal, and 0.1 atmospheres to the case where the chlorine is diluted by an inert gas. The beryllium chloride is also a vapor at normal casting temperatures and the equilibrium line for this species has been calculated assuming the pressure to be 0.1 atmospheres.

It is interesting to note that oxidizing with chlorine shifts the curves for the various elements to the left (i.e., to lower dissolved levels) when compared to Fig. 1. In fact, barium, strontium, and sodium are shifted so far to the left that they are off scale, and no longer appear in the figure. Gas fluxing with chlorine is seen to be an effective method to refine aluminum. Unfortunately, the use of chlorine gas also has potential safety and environmental problems. An alternative is to stir reactive chloride salts into the melt. ${ }^{4,5} \mathrm{~A}$ detailed theoretical study of fluxing was conducted in Japan. ${ }^{6}$ They made calculations similar to those given here, and calculated an equilibrium distribution ratio of each element between the metal and salt phases. For a flux containing $45 \mathrm{~mol} \% \mathrm{NaCl}-45$ mol\% $\mathrm{KCl}-10 \mathrm{~mol} \% \mathrm{AlCl}_{3}$, the following impurities can be removed: $\mathrm{Ho}, \mathrm{Dy}, \mathrm{Li}, \mathrm{La}, \mathrm{Mg}, \mathrm{Gd}, \mathrm{Ce}, \mathrm{Yb}, \mathrm{Ca}$, and Sr. The other 33 elements studied cannot be removed by fluxing. Most commercial fluxes are based on a eutectic mixture of $\mathrm{KCl}$ and $\mathrm{NaCl}$, which melts at $665^{\circ} \mathrm{C}$. Adding about $10 \% \mathrm{NaF}$ produces a ternary eutectic melting at $607^{\circ} \mathrm{C} . \mathrm{MgCl}_{2}$ - $\mathrm{KCl}$ fluxes are also popular, since this system has a eutectic melting at $424^{\circ} \mathrm{C}$.

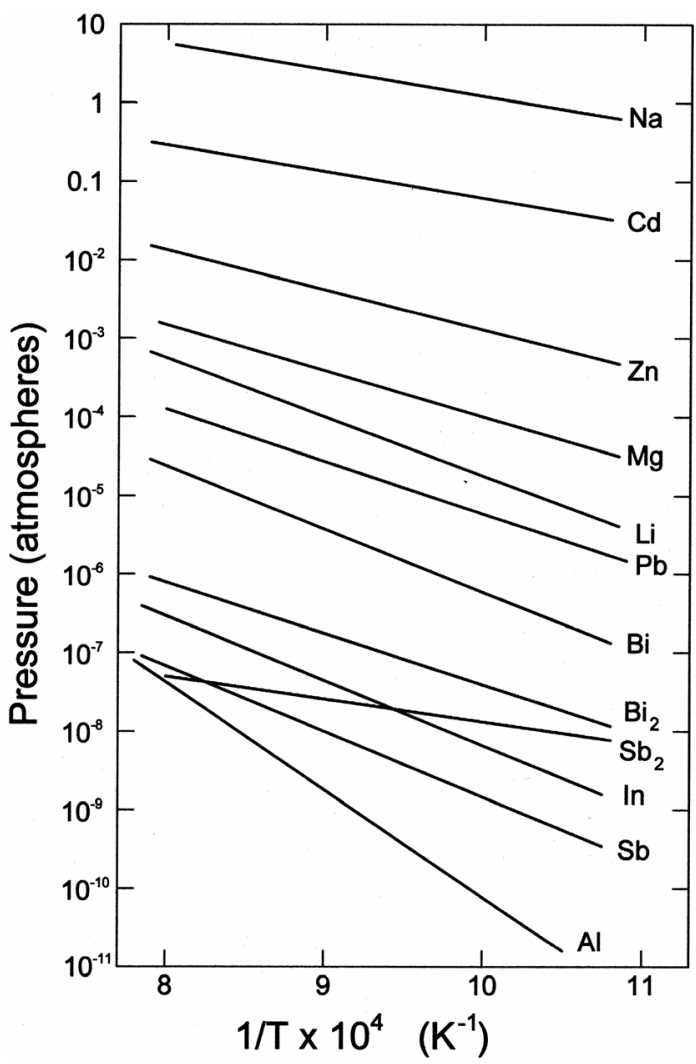

Fig. 3. Calculated vapor pressures in a 'hypothetical' $1 \mathrm{wt} \%$ solution.

Some elements have a vapor pressure higher than aluminum, and they might be removed selectively by vacuum treatment. Also, high vapor pressures may cause an unintentional loss of a desirable alloying element. We can examine these cases by using the data in Table I, together with information on the vapor pressure of the elements. ${ }^{1,7}$ Consider the element sodium:

\begin{tabular}{lcll}
\multicolumn{1}{c}{ Reaction } & Free energy $\left(\Delta \mathrm{G}^{\circ}\right)$ of reaction & & \multicolumn{1}{c}{ Source } \\
\cline { 1 - 1 }$(\mathrm{l})=\mathrm{Na}(\mathrm{v})$ & $98,570-83.806 \mathrm{~T}$ & & JANAF Tables $[1]$ \\
$\mathrm{Na}(\%)=\mathrm{Na}(\mathrm{l})$ & $-34,430+21.378 \mathrm{~T}$ & & Table I \\
$\mathrm{Na}(\%)=\mathrm{Na}(\mathrm{v})$ & $64,140-62.428 \mathrm{~T}$ & & Sum of the above
\end{tabular}

If the sodium concentration was equal to $1 \mathrm{wt} \%$, the equilibrium constant for reaction (15) would be numerically equal to the pressure of sodium. In other words:

$$
\begin{aligned}
\ln K_{15} & =\ln \left[\frac{P_{N a}}{\% N a}\right]=\frac{-64,140+62.428 T}{R T} \\
& =\frac{-7715}{T}+7.509
\end{aligned}
$$

The pressure given by Eq. (16) is plotted in Fig. 3. However, the solubility of sodium in aluminum at $1000 \mathrm{~K}\left(727^{\circ} \mathrm{C}\right)$ is only $0.2 \mathrm{wt} \%$. The one percent solution is therefore 'hypothetical', not actual. 
Table II. Approximate minimum concentrations to be realized by Vacuum refining at $1000 \mathrm{~K}$.

\begin{tabular}{lc}
\hline Dissolved element & Composition, ppm \\
\cline { 2 - 2 } $\mathrm{Na}$ & $4 \times 10^{-7}$ \\
$\mathrm{Cd}$ & $7 \times 10^{-6}$ \\
$\mathrm{Zn}$ & $3 \times 10^{-4}$ \\
$\mathrm{Mg}$ & $1.3 \times 10^{-2}$ \\
$\mathrm{Li}$ & $3 \times 10^{-2}$ \\
$\mathrm{~Pb}$ & 0.11 \\
$\mathrm{Bi}$ & 0.41 \\
$\mathrm{In}$ & 110 \\
$\mathrm{Sb}$ & 300 \\
\hline
\end{tabular}

Sodium also forms a diatomic vapor.

$\frac{\text { Reaction }}{2 \mathrm{Na}(1)=\mathrm{Na}_{2}(\mathrm{v})}$
$2 \mathrm{Na}(\%)=2 \mathrm{Na}(1)$
$2 \mathrm{Na}(\%)=\mathrm{Na}_{2}(\mathrm{v})$
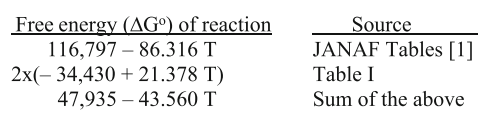

Table I Sum of the above

$$
\begin{aligned}
\ln K_{17} & =\ln \left[\frac{P_{N a_{2}}}{(\% N a)^{2}}\right]=\frac{-47,935+43.560 T}{R T} \\
& =\frac{-5766}{T}+5.239
\end{aligned}
$$

It is easily seen that

$$
\frac{P_{N a}}{P_{N a_{2}}}=\frac{K_{15}}{K_{17} \cdot \% N a}
$$

Hence, at low concentrations of sodium the monatomic vapor phase predominates. Typically, sodium contents are less than about $100 \mathrm{ppm}$. At $1000 \mathrm{~K}$ and this concentration, the equilibrium phase is more than $99 \% \mathrm{Na}(\mathrm{v})$. For this reason, the pressure of the diatomic vapor phase is not plotted in Fig. 3. The situation is similar in the case of bismuth, although both vapors are plotted. Antimony also has a $\mathrm{Sb}_{4}$ vapor, but this is not stable at the low concentrations of Sb normally encountered. Only the pressures of the monatomic and diatomic vapors are shown.

At the 'hypothetical' $1 \mathrm{wt} \%$ standard state, the equilibrium product is numerically equal to the vapor pressure. This pressure has been plotted as a function of temperature for selected elements in Fig. 3. The vapor pressure of aluminum is also shown for comparison, since it represents a limit on the vacuum that may be obtained to refine an alloy.

When a molten alloy is subjected to a vacuum, the most volatile elements would tend to boil off first. As these are depleted, less volatile species will be removed. This process continues until the pressure has decreased to the point where aluminum begins to be lost. Refining ends at this point, and may be roughly defined as when the pressure of the element to be removed is equal to that of aluminum. This simple approximation was used to make calculations at a temperature of $1000 \mathrm{~K}\left(727^{\circ} \mathrm{C}\right.$ or $\left.1340^{\circ} \mathrm{F}\right)$. The resulting limiting concentrations are given in Table II.

In practice, dissolved impurity element levels would be higher than those calculated in Table II, owing to kinetic factors. These have been discussed in some detail by Richardson. ${ }^{8}$ Kinetic factors were also considered by Engh. ${ }^{9}$

Figure 3 helps one understand how elements behave in molten aluminum. For example, if metallic sodium is added to modify aluminum-silicon alloys, the sodium recovery will be low, and a good portion of the addition will go into the plant's atmosphere, to create a nasty, irritating fume. Likewise, if zinc is alloyed at high metal temperatures, the $\mathrm{Zn}$ recovery is likely to be less than desired. The 7xxx alloys contains more than the $1 \%$ considered in Fig. 3, so the actual vapor pressure of zinc in these alloys will be five to ten times those plotted in Fig. 3.

With detailed thermodynamic information to hand, it is possible to evaluate the possibilities offered to us by thermodynamic laws and the chemical properties of individual elements. This capability is vital. Consider this example: A number of cerium-containing casting alloys have recently been developed for their high-temperature strength. ${ }^{10}$ Can we recycle these alloys by removing the dissolved Ce? Table I provides the free energy of solution for cerium. The JANAF tables do not list the free energies of formation for cerium compounds, but the following values are found in the excellent compilation by Engh: ${ }^{11}$

$\frac{\text { Reaction }}{\mathrm{CeCl}_{3}=\mathrm{Ce}+3 / 2 \mathrm{Cl}_{2}}$
$\mathrm{CeF}_{3}=\mathrm{Ce}+3 / 2 \mathrm{~F}_{2}$

Gibbs Free Energy (Joules/mol) $1,050,000-240 \mathrm{~T}$

$1,770,000-252 \mathrm{~T}$

I will leave the calculations as an exercise, but you will find that fluxing with chlorine or fluorine cannot remove Ce to levels less than about $5 \mathrm{wt} \%$.

It is also informative to look at the relative stability of the oxides. The values below are given by Engh. ${ }^{11}$

$\begin{array}{lc}\frac{\text { Reaction }}{\mathrm{Ce}_{2} \mathrm{O}_{3}=2 \mathrm{Ce}+3 / 2 \mathrm{O}_{2}} & \text { Gibbs Free Energy (Joules/mol) } \\ \mathrm{Al}_{2} \mathrm{O}_{3}=2 \mathrm{Al}+3 / 2 \mathrm{O}_{2} & 1,788,000-286.6 \mathrm{~T} \\ & 1,687,300-327 \mathrm{~T}\end{array}$

Looking only at these values, one might conclude that cerium oxide is more stable, and could be removed from aluminum by oxygen. However, the free of energy of solution of $\mathrm{Ce}$ in aluminum 
produces sufficient energy that $\mathrm{Al}-\mathrm{Ce}$ alloys can be produced by aluminothermic reduction. ${ }^{\S}$ The net result is:

$\frac{\text { Reaction }}{1 / 2 \mathrm{Ce}_{2} \mathrm{O}_{3}+\mathrm{Al}=\underline{\mathrm{Ce}}(\%)+1 / 2 \mathrm{Al}_{2} \mathrm{O}_{3}} \quad \frac{\text { Gibbs Free Energy (Joules/mol) }}{-120,100+12.073 \mathrm{~T}}$

The reaction as stated above is favorable, but it is also promoted by the formation of a compound between the two oxides: ${ }^{11}$

$\frac{\text { Reaction }}{\mathrm{Ce}_{2} \mathrm{O}_{3} \cdot \mathrm{Al}_{2} \mathrm{O}_{3}=\mathrm{Ce}_{2} \mathrm{O}_{3}+\mathrm{Al}_{2} \mathrm{O}_{3}} \quad \frac{\text { Gibbs Free Energy (Joules/mol) }}{79,500+20.9 \mathrm{~T}}$

Of course, this reaction is undesirable, since it lowers the recovery of cerium in the aluminothermic reduction process, and increases the amount of oxide dross produced.

Aluminum is an extremely reactive metal. It is more stable than most of the elements used to produce commercial alloys. This chemical property is why aluminum is produced electrochemically and not by carbothermic reduction. It is also why our ability to remove many elements is limited. Some of these are considered below. They are listed in the order of increasing distribution coefficients.

$$
\operatorname{Iron}\left(k_{\mathrm{Fe}}=0.027\right)
$$

Iron is much less reactive than aluminum, and has a high melting point and low vapor pressure. It cannot be removed by selective oxidation or vacuum refining. However, iron segregates strongly during solidification, and it is possible to purify $\mathrm{Al}-\mathrm{Fe}$ alloys by fractional crystallization. Metal producers have developed and used such a process. Details are not publically available. However, it is possible to offer a 'guesstimate'. Typical melting costs in the cast house are five to ten cents a pound. A fractional crystallization process will be more complicated. One must partially freeze the alloy, drain off the iron-rich liquid, and then re-melt and cast the low iron heel left in the furnace. Operating costs will be at least double that of a simple melting. Twenty cents a pound is probably a good estimate of operating costs.

The historical premium for lower iron sow (P0406 compared to P1020) has been six to eight cents a pound. This is less than the 20 cents a fractional crystallization process presumably costs. Thus, there appears to be little economic incentive for this option, except for the production of small volumes of special, very-high-purity alloys.

\footnotetext{
$\S_{\text {The value of }} \gamma^{\circ}$ for cerium in Table $\mathrm{I}$ is a very small value $(2.4 \times$ $10^{7}$ at $\left.1000 \mathrm{~K}\right)$. This means that Ce has a strong chemical affinity for aluminum. Its activity in liquid aluminum is more than a million times smaller than in an ideal solution. Another indication is found in the Al-Ce phase diagram. Numerous intermetallic compounds exist, and they have high melting points. The above calculations are a good example of why it is important to have the data given in Table I.
}

A study in China ${ }^{12}$ conducted electroslag refining trials, using a $\mathrm{KCl}-\mathrm{NaCl}-\mathrm{Na}_{3} \mathrm{AlF}_{6}$ flux containing $\mathrm{P}$. The results indicated that $\mathrm{Fe}_{2} \mathrm{P}$ was formed and removed in the process. However, the iron reduction was modest. Less than half was removed: the iron decreased from 0.48 to $0.30 \mathrm{wt} \%$.

$$
\operatorname{Silicon}\left(k_{\mathrm{Si}}=0.13\right)
$$

Like iron, silicon is less reactive than aluminum. It has a high melting point and low vapor pressure, and cannot be removed by selective oxidation or vacuum refining. However, silicon segregates during solidification, and it is possible to remove it by fractional crystallization. Unlike iron, silicon is a useful element in many aluminum alloys. So, it is more sensible to segregate scrap so its silicon can be recovered and used.

$$
\operatorname{Copper}\left(k_{\mathrm{Cu}}=0.17\right)
$$

Copper is similar to iron and silicon, and cannot be removed by selective oxidation or vacuum refining. It does not segregate as strongly during solidification. Hence, a fractional crystallization process would be possible, but less efficient. The comments above for iron also apply here. In other words, there appears to be no economical way to remove copper, once it is dissolved in aluminum. Good scrap segregation is probably the best way to recover copper-containing alloys.

Another possibility should be considered. Copper has the reputation of creating corrosion problems in most copper-free alloys. As an impurity element, a maximum limit of 0.05 or $0.1 \% \mathrm{Cu}$ is typical. A detailed study was undertaken by the VDS (the Society of German Smelters) and published in Metallurgia. ${ }^{13}$ This paper gave a detailed review of studies published before 1968, and concluded that, for atmospheric corrosion, copper additions $<0.4 \%$ had little or no effect. The data for exposure to liquid media was less convincing, so they conducted a study in a eutectic $\mathrm{Al}-\mathrm{Si}$ alloy under different corrosion conditions. The results showed no effect when $\mathrm{Cu}$ was $<0.24 \%$, and only a small effect at the next highest addition level of $0.52 \% \mathrm{Cu}$. This suggests that higher levels of copper can be tolerated in many alloys.

$$
\operatorname{Zinc}\left(k_{\mathrm{Zn}}=0.4\right)
$$

Zinc is similar to iron chemically, but it segregates weakly during solidification. It has a relatively high vapor pressure, so a vacuum refining process could be used. However, this would be rather expensive. Hence, there presently is no economical way to remove zinc from secondary aluminum alloys. Like copper, higher levels of zinc may be tolerated in many alloys. Tests have shown that reasonable amounts of zinc have no deleterious effect in most casting alloys. ${ }^{14}$ 


$$
\operatorname{Magnesium}\left(k_{\mathrm{Mg}}=0.51\right)
$$

As we saw in Figs. 1 and 2, magnesium is easily removed to low levels by fluxing with chlorine or fluorine salts.

$$
\text { Manganese }\left(k_{\mathrm{Mn}}=0.94\right)
$$

Manganese is similar chemically to iron, but it does not segregate during solidification. Hence, there is no way to remove it, once it is dissolved in aluminum. The challenge thus posed was solved in a unique way by Rheinfelden Aluminium, a small producer of specialty alloys located in southern Germany. They operated a secondary smelter that processed used beverage cans together with other packaging waste. The resulting metal was relatively high in manganese. In looking for ways to use this secondary metal, Rheinfelden developed a series of new alloys for high-pressure die-casting. Conventional die-casting alloys are high in iron, needed to reduce die wear. (Hot liquid aluminium low in iron wants to dissolve the tool steel dies.) Unfortunately, the high iron content lowers casting ductility. Rheinfelden used Mn to replace most of the iron in their die-casting alloys. The result was a reasonable die life, together with the ability to produce highductility, structural die castings. These new alloys are now finding extensive commercial use. For example, structural automotive components are cross-members, engine cradles, shock towers, and door pillars. The result is a lighter and more fuelefficient automobile, and a new way to recycle secondary alloys containing manganese. Further details of this exciting new development are available elsewhere. ${ }^{15,16}$

Other reviews of possible refining reactions and metal recycling have been presented. ${ }^{17-19}$ They suggest that we must do a better job of sorting and labeling scrap, and physically removing possible contaminants, for example, by improved shredding and sorting.

It is worth noting that Kagawa and Tabira ${ }^{20}$ conducted a detailed study of distribution coefficients and the freezing point depression in multicomponent systems. Interaction coefficients and equations were given, which can be used to calculate distribution coefficients in alloy systems, which are more complicated than binary (two-component) alloys.

\section{CONCLUSION}

Thermodynamic laws are immutable, but economic conditions change. For example, the LME price for primary aluminum has increased by US $\$ 1000$ a tonne during the last year. Thus, refining schemes that historically have not been economical may become so in the future. It would therefore be provident to conduct additional research and development on new processes, or improved versions of older processes, to refine secondary metal. It is possible that improved electrolytic refining or fractional crystallization processes can make an important future contribution to our recycling of secondary aluminum.

The search for new refining processes can be facilitated by using computer-based thermodynamic tools. Thermocalc, Pandat, and Factsage are programs with which I have some familiarity, but others are also available. These programs are now quite sophisticated and can be extremely useful. ${ }^{\text {}}$ With these programs, one may quickly evaluate the possible use of adding an element ' $\mathrm{X}$ ', for example, to remove iron by precipitation of an intermetallic compound with iron ('FeX'). This compound could then be removed by filtration or sedimentation. Many proposed refining processes can be quickly evaluated in this manner; and promising schemes identified for additional laboratory study or pilotscale development.

There also appears to be room in many cases for a more intelligent design of aluminum alloys. Some of the alloy composition limits we use now are historical artifacts, and could be modified to promote recycling. Consider that many of our foundry alloys were developed during and shortly after World War II to have chemistry specifications compatible with the mix of zinc, copper, manganese, and magnesium in secondary aluminum coming from the alloys used in aircraft construction during the war. ${ }^{21}$ It is more sensible to develop casting alloys better suited to the composition of secondary aluminum now available. The Mn-containing alloys developed for structural high-pressure die castings are an excellent example of intelligent design; but there must be many other opportunities for clever metallurgists to discover.

\section{ACKNOWLEDGEMENTS}

The author gratefully acknowledges the Reynolds Consumer Products Company. Reynolds provided financial support for a portion of this study.

\section{CONFLICT OF INTEREST}

The author states there are no conflicts of interest.

\section{SUPPLEMENTARY INFORMATION}

The online version contains supplementary material available at https://doi.org/10.1007/s11837021-04774-z.

\footnotetext{
${ }^{\S}$ Unfortunately, computer-based simulations sometimes fail to give an accurate representation of activities in dilute alloys of aluminum. These problems are discussed in the electronic supplementary material accompanying this article. Please consider Figures S-1 and S-2, and the accompanying discussion.
} 


\section{REFERENCES}

1. D.R. Stull, and H. Prophet, JANAF Thermochemical Tables, 2nd edn, NSRDS-NBS 37 (DC, National Bureau of Standards, Washington, 1971).

2. G. Dubé, V.J. Newberry, Light Metals, 1983, (Warrendale, $\mathrm{Pa}$ : The Minerals, Metals and Materials Society, 1983) pp. 991-1003.

3. R.D. Peterson, X. Wang, Light Metals 1991, (Warrendale, $\mathrm{Pa}$ : The Minerals, Metals and Materials Society, 1991) pp. 331-337.

4. G. Lofstrom, Solid Salt Fluxing of Molten Aluminum, M.S. Thesis, Ohio State University (2013).

5. T.A. Utigard, R.R. Roy, and K. Friesen, Can. Metall. Q. 40, 327. (2001).

6. T. Hiraki, T. Miki, K. Nakajima, K. Matsubae, S. Nakamura, and T. Nagasaka, Materials 7, 5543. (2014).

7. R. Hultgren, P.D. Desai, D.T. Hawkins, M. Gleiser, and K.K. Kelly, Selected Values of the Thermodynamic Properties of The Elements (American Society for Metals, Metals Park Ohio, 1973).

8. F.D. Richardson, Physical Chemistry of Melts in Metallurgy, vol 2. (Academic, New York, 1974), pp 477-487.

9. T.A. Engh, Principles of Metal Refining (Oxford University Press, Oxford, 1992), pp 207-214.

10. H.B. Henderson, D. Weiss, Z.C. Sims, M.J. Thompson, E.E. Moore, A. Perron, F. Meng, R.T. Ott, O. Rios, Light Metals, 2020, (Pittsburgh, Pa: The Minerals, Metals \& Materials Society, 2020) pp. 227-232.
11. T.A. Engh, Principles of Metal Refining (Oxford University Press, Oxford, 1992), pp 407-425.

12. C. Chen, J. Wang, D. Shu, P. Li, J. Xue, and B. Sun, Mater. Trans. 52, 1629. (2011)

13. Anonymous, Metallurgia, 77, 103 (1968)

14. D.L. Colwell, Trans. Am. Foundry Soc. 60, 517. (1952).

15. U. Hielscher, H. Sternau, H. Koch, US Patent 6364970B1, April 2, 2002

16. G.K. Sigworth, and R.J. Donahue, Int. J. Metalcast. https://d oi.org/10.1007/s40962-020-00535-x (2020).

17. K. Nakajima, O. Takeda, T. Miki, K. Matsubae, S. Nakamura, and T. Nagasaka, Environ. Sci. Technol. 44, 5594 (2010).

18. L. Zhang, X. Lu, A.T. Torgerson, M. Long, Miner. Process. Extr. Metall. Rev., 32, 150 (2011-2012).

19. G. Gaustad, E. Olivetti, and R. Kirchain, Resour. Conserv. Recycl. 58, 79. (2012).

20. A. Kakagawa, Y. Tabira: Mater. Trans., JIM, 32, 1076 (1991).

21. E. Rooy, AFS International Conference on Structural Aluminum Castings, Proc. Conference Nov. 2-4, 2003, Orlando Florida (Des Plaines, Illinois: American Foundry Society, 2003), pp. 87-98.

Publisher's Note Springer Nature remains neutral with regard to jurisdictional claims in published maps and institutional affiliations. 